\title{
In Remembrance
}




\section{Hugo Hantsch}

For three decades Austria's major historian in the area of Habsburg scholarship was Hugo Hantsch, who died in Vienna on August 6, 1972. Born in Teplitz-Schönau, Bohemia, on January 15, 1895, Hantsch belonged to a generation of Central Europeans who witnessed more upheavals and more profound transformations than any other generation born in the nineteenth or twentieth centuries. He grew up as one of nine children of a German-Bohemian middle class family in northern Bohemia. He also spent some time in Prague. His contact there with people of different national origins or religious persuasions was an experience which Hantsch valued highly.

At the age of eighteen Hantsch left Bohemia for the heartland of the Habsburg empire; he was admitted as a novice to the great Benedictine convent of Melk, in Lower Austria, whose abbot, Amand John, was one of his great-uncles. In 1918 he was ordained a priest: Hantsch spent most of the war years studying theology at Innsbruck. Studies in law and, above all, history followed, and Hantsch received his $\mathrm{Ph}$. D. in history at the University of Innsbruck in 1921. A close feeling of mutual respect and sympathy developed between Hantsch and his main teacher at the university, the historian Harold Steinacker, who was, incidentally, a Protestant. Perhaps Hantsch's own generous and liberal attitude towards students with other religious beliefs developed from this association. Hantsch's doctoral dissertation dealt with the history and nature of the vows in the Order of Saint Benedict. Parts of it were published as late as 1960 in the Austrian Archiv für Kirchenrecht and the Mitteilungen des Instituts für österreichische Geschichtsforschung. The University of Innsbruck conferred the degree of LL. D. honoris causa on Hantsch shortly before his death.

Although Hantsch was originally expected to teach at the Stiftsgymnasium in Melk, the talents, interests, and qualifications which he discovered or acquired during his years of study now led him in a different direction. It was decided that he should devote himself to the more ambitious task of historical scholarship and writing. The middle 'twenties were years of intensive archival work, advanced study, and writing. After spending two years as archivist for the House of Schönborn, in Franconia, Hantsch went to Vienna for specialized training in the Institut für österreichische Geschichtsforschung. At the same time, he began publishing a number of monographs. In 1925 his study of the German Peasants' War appeared in print. The next year he published a volume on Jakob Prandtauer, the architect of the baroque age, who 
built the magnificent monastery of Melk. Three years later, in 1929, perhaps the most enduring of his early works was printed: his monograph on Count Friedrich Karl von Schönborn (1674-1746), vicechancellor of the Holy Roman Empire in the early part of the eighteenth century and subsequently Bishop of Bamberg and Würzburg. These three monographs, appearing in rapid succession and testifying to Hantsch's creative powers as a historian, reveal the characteristic trait of Hantsch's writing: his ability to delineate the interplay of landscape, culture, individual personalities, and groups of men on a broad canvas. For him, as for many of his contemporaries, culture (Kultur) had a comprehensive meaning; it was a term of as central significance in the 1920's as the term "society" is in our own day. Elements of a romantic tradition are visible in his descriptions of landscape, whether that of Franconia or that of the Danube Valley near Melk. Landscape became an integral part of the cultural milieu and bore the indelible stamp of the people living in it and the buildings erected on it; it became a Kulturlandschaft.

Two decades later, after the traumatic experience of the rise and fall of National Socialism, Hantsch reflected on the respective roles of culture and politics in human history. Cultural values and achievements, he wrote in 1948 in his important essay "Die Krise der Geschichtsauffassung," published in the review Wissenschaft und Weltbild, endure beyond the vicissitudes of politics. While the aims of politics were strictly limited, culture was limited, Hantsch said, at most by man's capacity to absorb it. In other words, politics was a limited sphere of human activity; culture, on the other hand, influenced the whole human personality. Above all, Hantsch believed that "religion and religious belief are the most profound and moving manifestations of cultural life" (in his essay "Das gesamtdeutsche Problem," in Monatsschrift für Kultur und Politik [1936]).

Yet it would be a mistake to look for artificially separate realms of culture and politics in Hantsch's writings. Hantsch was fully aware that the age of the baroque, whose traditions surrounded him in Melk, Franconia, and Vienna, was an age of synthesis. And there is an additional point to be made: in the tradition of Johann Gottfried Herder, he believed that a people could be defined only in cultural and never in political terms. We find a close connection, particularly in Hantsch's writings in the 'thirties, between culture and a people's character, between culture and Volkstum. The cultural tasks and achievements of the German Austrians within the Habsburg monarchy, from the time of the monarchy's expansion into southeastern Europe during the era of Prince Eugene to the last decades of the empire's existence, looms large in his works. 
The way for Hantsch's academic career was opened up with the publication of his monograph on Count Schönborn, a man who had striven against overwhelming odds to maintain, or rather to revive, the imperial idea (Reichsidee) in the face of the consolidation of the territorial states. With the active sponsorship of Heinrich von Srbik, Hantsch became a docent at the University of Vienna in 1930. Five years later, in 1935, he was appointed professor extraordinarius (associate professor) of Austrian history at the University of Graz.

In the meantime, he continued his remarkably high rate of productivity. In 1933 he published his work on the rise of Austria as a Great Power, Die Entwicklung Österreich-Ungarns zur Großmacht, which was actually a parallel volume to Max Braubach's book on the rise of Prussia. Centering on the seventeenth and eighteenth centuries and terminating in 1815, Hantsch's study dealt with the period of Habsburg greatness that had already become familiar to him as a consequence of his earlier biographies of men of the baroque era. It also included the story of the great conflict with Prussia in the middle of the eighteenth century. With asperity, Hantsch described the loss of Silesia as an event of great magnitude in a process that led to the weakening and final destruction of the Holy Roman Empire and the ultimate ousting of the Habsburgs from a greater Germany, as delimited, first, by the Holy Roman Empire and subsequently by the German Confederation.

A year later, in 1934, Hantsch published a small interpretative volume, Österreich-Eine Deutung seiner Geschichte und Kultur, based on lectures he had delivered in Salzburg in the summer of 1933, a few months after Hitler assumed power in Germany. In it, as in his other writings in the 'thirties, Hantsch revealed the special nature of his commitment to a gesamtdeutsch interpretation of history. There can be no question that his strong commitment both to Catholicism and to the Habsburg dynasty provided a contrast to Srbik's concepts. Stressing the impact of the Latin world on A ustrian history, Hantsch maintained that the "casa d'Austria" had firm roots on Latin soil. The imperial idea, he asserted, was in contradiction to the notion of the intellectual and religious separation of the Germanic and Latin worlds.

After Hitler's rise to power in Germany, Hantsch actively participated in the desperate struggle of Chancellors Engelbert Dollfuß and Kurt von Schuschnigg to maintain Austria's independence. He took part in Austria's efforts to protect "Volksdeutsche" living in the Successor States of the Habsburg monarchy (in an older terminology, German Austrians who had lived in various parts of the multinational empire) against the torrent of propaganda emanating from Nazi Germany. Arguing against the leveling and centralizing aspects of the Nazi 
ideology, Hantsch pleaded for a plurality of ways of being German. He invoked the motto "In necessariis unitas, in dubiis libertas, in omnibus autem caritas" ("Das gesamtdeutsche Problem" [1936])!

His reward for political commitment came immediately after the Nazi occupation of Austria. Not only did he lose his professorship at the University of Graz; he also was imprisoned and sent to Buchenwald Concentration Camp. In 1939 he was released only on condition that he be confined to Ravelsbach, a little village in Lower Austria, where he became the parish priest. He was not permitted to publish. Hantsch's great spiritual resources, both as a man and as a priest, enabled him to master the situation imposed on him by the Hitler regime. And, in retrospect, he looked upon his years as Seelsorger at Ravelsbach with gratitude for the new experience, both human and spiritual, which he enjoyed while pastor.

After the reestablishment of Austrian independence, Hantsch returned to the University of Graz, now as full professor. (Because of the Nazi occupation, his nomination as ordinarius in 1938 had remained ineffective.) In 1946 he was called to the University of Vienna to succeed Heinrich von Srbik, who had been obliged to retire for well-known political reasons. (Hantsch always courageously voiced his respect for Srbik's scholarship during the time when Srbik was persona non grata.) From 1946 until his retirement in 1966 he was professor of modern history and director of the historical institute at the University of Vienna.

Hantsch's scholarly and academic life thus was forcibly interrupted by the Nazis nel mezzo del camin di sua vita. While the first volume of his greatest work, Die Geschichte Österreichs, was published in 1937before the interlude of silence to which he was condemned between 1938 and 1945-the second volume appeared thirteen years later in 1950. In spite of this long publication gap, the volumes constitute a unified entity. As Prof. Günther Hamann has said, Hantsch's Geschichte Österreichs represents a rare and courageous instance of historical synthesis at a time when historical scholarship threatens to fall into disjointed pieces of specialized work. Hantsch carried the account in his first volume to the end of the Thirty Years' War, thus stressing the essential continuity of Austrian history from the late middle ages to early modern times. The second volume concludes with the end of the First World War and the Treaty of Saint Germain. For a long time Hantsch contemplated writing a third volume on the history of the First Austrian Republic, but this volume remained unwritten, perhaps because the world whose historian he had become had come to an end in 1918.

Hantsch's stressing of the central role of the dynasty and the Catholic 
Church in the development of an empire that transcended ethnic and national boundaries is apt to evoke the epithet "conservative" in describing his work. However, it should be pointed out that Hantsch has been critical of many aspects of the Habsburg monarchy; more so, in fact, than we may be willing to admit in our contemporary climate of opinion, prone to condemn much of what Hantsch stood for. Hantsch's critical remarks about the Austrian nobility in the nineteenth century, as well as some of his observations concerning the imperial bureaucracy, are cases in point. If a part of Die Geschichte Österreichs may be singled out where Hantsch's beliefs stand out with special clarity, his chapters on Joseph II and "the universal claim of the total state" should be mentioned. The secularization of thought in the Enlightenment, Hantsch argued, has led directly to the monopolistic claim of the state to regulate everything. Pure reason detached from religious belief ended in hubris (souveräne Selbstüberschätzung).

Beyond the substance of Hantsch's work we must not overlook the merits of style and presentation. Hantsch described and painted in many colors, and he never was led astray by abstract disquisitions. Unlike many historical works written in German, Die Geschichte Österreichs is an eminently readable book.

From the time of his appointment to the University of Vienna until his death Hantsch was accorded many honors and burdened with numerous academic and scholarly duties, only a few of which will be mentioned here. Among them was membership in the Austrian Academy of Sciences, the deanship of the Faculty of Philosophy (19561957), the chairmanship of the Commission for Modern Austrian History (1947-1967), and leading positions in the Viennese Catholic Academy and the Research Institute on the Danubian Area in Vienna. After his retirement from the university he continued to live in the Melkerhof in Vienna, as he had for two decades. From 1959 until his death in 1972 he was chairman of the Austrian Academy of Sciences' Commission for the History of the Austro-Hungarian Monarchy.

During the last quarter century of his life Hantsch turned his attention increasingly to the last years of the Habsburg monarchy. If the baroque age had been his main scholarly interest during his early years as a historian, the monarchy's decline in the age of liberalism and nationalism occupied most of his scholarly attention after 1945. Both before and after the great caesura in Hantsch's middle life, political history had, after all, absorbed most of his energies as a historian, though not, perhaps, his interests as a human being. In 1953 he published a book in the nationality question. Its subtitle, Das Problem der konstruktiven Reichsgestaltung, suggests the main theme of his inquiry 
in this useful and informative volume. In 1962 his last book, a twovolume biography of Count Leopold Berchtold, appeared in print. The work suffers, perhaps, from too much empathy with Berchtold, which prevented Hantsch from showing as much critical detachment in his analysis of the count as might have been expected.

Hantsch's interest in the last phases of the Danubian monarchy's history, as well as in the lessons which the problems of this period might teach to those seeking cooperation or integration on a European level, focused increasingly on a large project: the publication of a multivolume, multinational, collective scholarly work discussing in depth the history of the monarchy from the Revolution of 1848 to the end of the First World War. It was in pursuit of this project that Hantsch visited the United States in 1957-a visit which, incidentally, encouraged the creation of the Conference Group for Central European History at the American Historical Association Convention in New York City in December, 1957. In his efforts to enlist the cooperation of scholars in many countries for his project, Hantsch was immensely gratified by the response in America that materialized in the founding of the Austrian History Yearbook.

In Austria, Hantsch's project was organized under the auspices of the Austrian Academy of Sciences, which, in 1959, established a Commission for the History of the Austro-Hungarian Monarchy to forward the study. Thereafter, especially after his retirement in 1966, he concentrated his energies on planning for and supervising the work prepared under the auspices of the Commission. Beginning in 1963 a series of monographs entitled Studien zur Geschichte der österreichischungarischen Monarchie began publication. Ten volumes appeared during Hantsch's lifetime. The cooperation between the Austrian Academy of Sciences' Commission and the Austrian History Yearbook is well known to the readers of the Yearbook. Hantsch hoped to live long enough to supervise the publication of all the volumes of Die Habsburgermonarchie 1848-1918. When he died, however, only the first volume, dealing with economic developments, was ready for the printer. It was published in 1973. It is dedicated to the memory of Hugo Hantsch, "who saw in this work which he had planned and organized the fulfillment of his travail for a just judgment of the multinational empire of the Habsburgs."

Hantsch combined conservative beliefs and a certain patriarchal demeanor with curiosity about new historical problems or new approaches to historical scholarship and tolerance towards views other than his own into a truly remarkable-or should we say "Benedictine"synthesis. His essays in Wissenschaft und Weltbild on fundamental 
problems of historical scholarship, particularly "Die Krise der Geschichtsauffassung" (1948) and "Zur Methodik der neueren Geschichtsschreibung" (1952), deserve re-reading today. The American reader will be surprised to discover how many British and American historians are referred to by Hantsch (who beginning around 1930 developed considerable interest in British history). Among them are Samuel Gardiner, Herbert Butterfield, A. L. Rowse, Arnold Toynbee, Frederick Jackson Turner, and Charles Beard. As early as 1952 Hantsch wrote: "We must face the fact that the social sciences have developed in a way that forces the historian to confront them." Ranke and his school, he maintained, had put political things into the forefront and had either pushed social movements to the periphery or ignored them; we cannot afford this, he admonished. Technical and economic developments influence mankind to such a great extent, Hantsch continued, that the historian cannot pass them by with a few superficial observations. In his advanced seminars at the University of Vienna, Hantsch discussed such diverse topics as Toynbee's History or the history of socialism. He also was the first historian to introduce contemporary history to the University of Vienna. As early as the winter term of 1950-1951 he gave a seminar on diplomatic relations between Austria and Germany from July, 1936, to March, 1938-in other words, on events which were then no more remote than twelve to fourteen years!

Hantsch's students, of whom this writer was one, will never forget the generosity and energy with which he encouraged and guided younger historians strictly according to talents and merits, without regard to differing denominational or philosophical convictions. His was the broad-mindedness of a man who believed in the biblical saying that there are many rooms in Heaven-or, in the words of a motto that Hantsch used in his writings and which pertains so well to him: In necessariis unitas, in dubiis libertas, in omnibus autem caritas. ${ }^{1}$

University of Vienna

Gerald STOURzH

With the death of Hugo Hantsch, the Austrian History Yearbook lost a friend who had significantly assisted a fledgling editorial enterprise.

'For other tributes to Prof. Hantsch, see especially Günther Hamann's funeral oration at the Melk Stiftskirche on August 11, 1972, which was published in Österreich in Geschichte und Literatur, Vol. XVI (1972), pp. 534-538. See also the memorial articles by Günther Hamann and Robert A. Kann in ibid., pp. 529-534 and 538-540; and Heinrich Lutz, "In memoriam Hugo Hantsch," Mitteilungen des Instituts für Österreichische Geschichtsforschung, Vol. LXXXI (1973), pp. 231-240. A detailed bibliography of Hantsch's writings is appended to Günther Hamann, "Hugo Hantsch," Österreichische Akademie der Wissenschaften, Almanach für das Jahr 1973(Vienna, 1974), pp. 338-367. 
Over the years he generously shared the time of his research assistants so that they could seek out information or accept editorial responsibilities for the Yearbook during time that would otherwise have been devoted to his own research. He could always be counted on to give candid and wise advice whenever called upon to do so, and he encouraged the editor in every possible way. The undersigned will always remember with affection and gratitude the image of Prof. Hantsch, at the 1965 International Congress of Historical Sciences, as he enthusiastically displayed the first issue of the Yearbook and encouraged his many friends to become subscribers.

Prof. Hantsch's interest in the Austrian History Yearbook was but one reflection of his great interest in Habsburg research in the United States and Canada. He freely gave his time to advising all who came to him for counsel, and he encouraged them at every turn. Not only the editorial staff of the Yearbook but also all American scholars studying the history of the Habsburg monarchy mourn his death.

R. J. R. 